\title{
Nitrate Assimilation in the Basidiomycete Yeast Sporobolomyces roseus
}

\author{
By A. H. ALI AND C. R. HIPKIN* \\ Department of Botany and Microbiology, University College of Swansea, Singleton Park, \\ Swansea SA2 8PP, UK
}

(Received 5 December 1984; revised 5 March 1985)

\begin{abstract}
Ammonium-grown cultures of Sporobolomyces roseus developed the capacity to assimilate nitrate when they were incubated in nitrate or nitrogen-free medium. Cycloheximide, 6-methyl purine and antimycin $\mathrm{A}$ inhibited this process. Nitrate assimilation required aerobic energy metabolism and was inhibited completely by ammonium. The rapid inhibition of nitrate assimilation by ammonium was not the result of an inhibition of nitrate reductase (NR) activity. Nitrite also inhibited nitrate assimilation. NR in cell-free extracts of $S$. roseus was NADPHspecific and its activity was repressed in cultures containing ammonium and derepressed during nitrogen starvation. Nitrate stimulated the appearance of NR in these cultures. Nitrate assimilation was not limited by apparent (potential) NR activity.
\end{abstract}

\section{INTRODUCTION}

Many autotrophic and heterotrophic micro-organisms are able to assimilate nitrate (Payne, 1973; Brown et al., 1974) and this process has been studied extensively in bacteria, cyanobacteria, algae (Guerrero et al., 1981) and filamentous ascomycetes such as Aspergillus (Pateman \& Kinghorn, 1976) and Neurospora (Garrett \& Amy, 1978). Surprisingly, there have been few detailed investigations of nitrate assimilation in yeasts and fewer in basidiomycetes.

In this paper we describe some aspects of the uptake and reduction of nitrate by the basidiomycete yeast Sporobolomyces roseus. This species occurs commonly in nature and is a frequent and often abundant member of the phylloplane and atmospheric microflora (Last, 1955; Gregory \& Hirst, 1957). Both nitrate and reduced nitrogen are likely to be important sources of nitrogen for phylloplane fungi although, to our knowledge, there have been no published investigations of nitrate assimilation in $S$. roseus. The work described here is part of a larger study of nitrate assimilation in yeasts.

\section{METHODS}

Organism and culture. Sporobolomyces Y44 was a generous gift from the Department of Botany, University of Bristol, UK. This organism, originally isolated from a phylloplane association at Long Ashton Experimental Station, Bristol, UK, has been identified by us as $S$. roseus as described by Phaff (1970). The liquid mineral medium minus nitrogen and carbon was that described by Ferguson \& Sims (1971). Carbon was supplied as glucose $(1 \%, \mathrm{w} / \mathrm{v})$ and nitrogen as $\mathrm{NH}_{4} \mathrm{Cl}$ or $\mathrm{NaNO}_{3}(10 \mathrm{~mm})$. Liquid cultures were usually grown for $3 \mathrm{~d}$ at $15^{\circ} \mathrm{C}$ in $100 \mathrm{ml}$ medium in $250 \mathrm{ml}$ Erlenmeyer flasks in an orbital incubator $(110$ r.p.m.). Cultures were inoculated from stocks kept on malt extract agar plates.

Organisms were harvested by centrifugation and washed with nitrogen-free medium (with or without $1 \%$, w/v, glucose) or buffer before uptake experiments or enzyme extraction respectively.

Uptake experiments. Inorganic nitrogen uptake was measured by following the disappearance of nitrate, nitrite or ammonium from the medium with zero-time culture densities of $10^{8}$ organisms $\mathrm{ml}^{-1}$. Nitrate was measured in supernatants by the method described by Cawse (1967), nitrite was measured by the Griess-1losvay Method as described by Everest $e t$ al. (1984) and ammonium and intracellular nitrate were measured as described by Cresswell \& Syrett (1979). Samples of $5 \mathrm{ml}$ or $10 \mathrm{ml}$ were withdrawn at each sampling time and results were expressed as means of duplicates. The results obtained were reproducible in repeated experiments.

Abbreviation: NR, nitrate reductase. 
Nitrate reductase $(N R)$ assays. NAD(P)H-NR activity was measured in cell-free extracts. Cells (approximately $10^{10}$ organisms) were broken in $10 \mathrm{ml} 50 \mathrm{~mm}$-potassium phosphate buffer $\mathrm{pH} 7.5$ containing dithiothreitol (1 $\left.\mathrm{mM}\right)$ and $\mathrm{Na}_{2}$ EDTA $(1 \mathrm{mM})$ by passage through a French pressure cell at $100 \mathrm{MPa}$. Extracts were clarified by centrifugation at $40000 \mathrm{~g}$ for $20 \mathrm{~min}$ at $3{ }^{\circ} \mathrm{C}$. Assays containing extract (about $500 \mu \mathrm{g}$ protein), potassium phosphate buffer $\mathrm{pH} 7.5(50 \mu \mathrm{mol}), \mathrm{KNO}_{3}(50 \mu \mathrm{mol}), \mathrm{FAD}(2.5 \mathrm{nmol})$ and $\mathrm{NAD}(\mathrm{P}) \mathrm{H}(0.3 \mathrm{mM})$ were initiated by the addition of $\mathrm{NAD}(\mathrm{P}) \mathrm{H}$, allowed to proceed for $10 \mathrm{~min}$ at $30^{\circ} \mathrm{C}$ and terminated by boiling for $2 \mathrm{~min}$. After cooling, residual NAD $(\mathrm{P}) \mathrm{H}$ was oxidized with phenazine methosulphate (Scholl et al., 1974) and nitrite was estimated.

Terminal-NR (BVH-NR) activity was assayed in cell-free extracts as described above except that benzyl viologen $(200 \mu \mathrm{g})$, reduced chemically with a sodium dithionite $(800 \mu \mathrm{g}) /$ sodium bicarbonate $(800 \mu \mathrm{g}) \mathrm{mixture}$, replaced NAD(P)H as an electron donor. Assays were terminated by vigorous mixing on a vortex mixer. BVH-NR activity was also measured in frozen/thawed cell preparations. In these experiments duplicate $1 \mathrm{ml}$ samples $\left(10^{8}\right.$ organisms) were centrifuged and resuspended in $50 \mathrm{mM}$-potassium phosphate buffer $\mathrm{pH} 7 \cdot 5$, containing $5 \mu \mathrm{M}-$ flavin adenine dinucleotide and frozen overnight at $-20^{\circ} \mathrm{C}$. Suspensions were thawed slowly and assayed for enzyme activity as described above.

Protein determination. Protein in cell-free extracts was determined by the method described by Hartree (1972).

\section{RESULTS}

\section{Development of the capacity to take up nitrate}

Cultures of $S$. roseus grown with nitrate or nitrite as the sole source of nitrogen were able to take up nitrate immediately when resuspended in fresh medium containing $1 \mathrm{mM}-\mathrm{KNO}_{3}$. In contrast, with ammonium-grown cultures there was a lag of $50 \mathrm{~min}$ before nitrate uptake commenced (Fig. 1a). However, when ammonium-grown cultures were nitrogen-starved with a carbon source (glucose) for $4 \mathrm{~h}$, nitrate was taken up without a lag (Fig. 1b). The capacity to take up nitrate immediately was not developed in ammonium-grown cultures that were nitrogenstarved in the absence of a carbon source (Fig. $2 a$ ) or if cycloheximide (an inhibitor of protein synthesis), 6-methylpurine (an inhibitor of functional mRNA synthesis) or antimycin A (an inhibitor of oxidative energy production) were present during nitrogen starvation (Fig. $2 b$ ). In these experiments (Fig. 2), the capacity to take up nitrate did develop after a further lag period if glucose was supplied to carbon-starved cells (Fig. $2 a$ ) or after the removal of inhibitors (Fig. $2 b$ ).

\section{Some characteristics of nitrate uptake by S. roseus}

In these experiments nitrate uptake was investigated with nitrate-grown cultures or ammonium-grown cultures that had been nitrogen-starved, i.e. cultures that had developed the capacity for nitrate uptake.

Little or no nitrate was taken up by cultures incubated in the absence of a carbon source (Fig. $3 a$ ), under anaerobic conditions (Fig. $3 b$ ) or in the presence of glucose, air and antimycin A (Fig. $3 c$ ).

The addition of $1 \mathrm{mM}$-ammonium to cultures resulted in a rapid and complete inhibition of nitrate uptake (Fig. 4a). Ammonium was taken up rapidly by these organisms and nitrate uptake recommenced only when the ammonium concentration of the medium fell to below $0.2 \mathrm{mM}$. However, these organisms took up nitrate more rapidly after ammonium inhibition had been relaxed $\left[7.5 \mathrm{nmol} \mathrm{NO} \mathrm{Nin}_{3}^{-1} \mathrm{~min}^{-1}\left(10^{8} \text { cells }\right)^{-1}\right]$ than they did before ammonium addition [5.8 $\left.\mathrm{nmol} \mathrm{NO}-\mathrm{min}^{-1}\left(10^{8} \text { cells }\right)^{-1}\right]$. The addition of $0.2 \mathrm{~mm}$-nitrite to cultures taking up nitrate resulted in a $43 \%$ inhibition of nitrate uptake. In these cultures nitrate and nitrite were taken up concurrently (Fig. 4b). Higher concentrations of nitrite $(>1 \mathrm{~mm})$, which are toxic to Sporobolomyces, prevented nitrate uptake completely (not shown).

We were unable to measure intracellular nitrate in $S$. roseus cells under any conditions.

\section{Nitrate reduction and nitrate assimilation in $S$. roseus}

Nitrate reductase (NR) was measured in cell-free extracts of nitrate-grown cultures (Table 1). The enzyme was active with NADPH as an electron donor but required the addition of flavin adenine dinucleotide for maximum activity; flavin mononucleotide could not replace the latter. The enzyme was not active with NADH as an electron donor whether flavin adenine dinucleotide was present or not. Terminal NR activity, measured with reduced benzyl viologen 


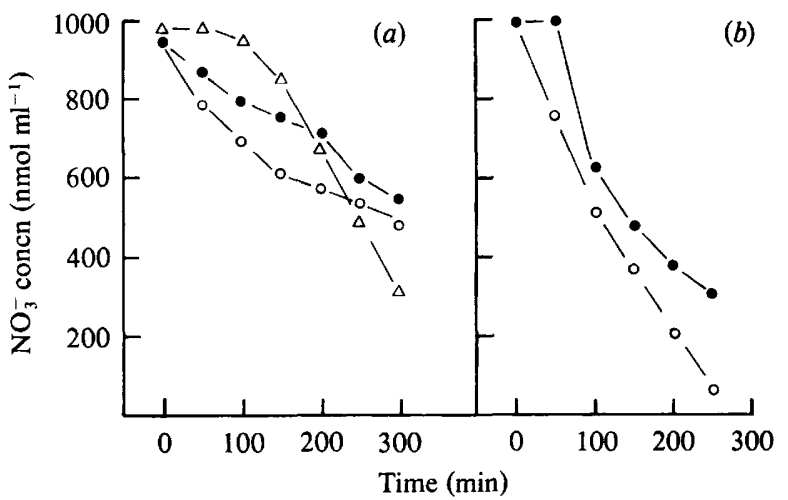

Fig. 1. Development of the capacity to take up nitrate. (a) Cultures grown on ammonium $(\triangle)$, nitrite (O) or nitrate $(O)$ as sole nitrogen source were transferred to medium containing 1 mM-nitrate. (b) Cultures grown on ammonium were transferred to medium containing $1 \mathrm{~mm}-\mathrm{KNO}_{3}: \mathrm{O}$, cultures that were nitrogen-starved in nitrogen-free medium for $3 \mathrm{~h}$ before nitrate addition; $\boldsymbol{O}$, cultures that received nitrate without prior nitrogen starvation. All cultures contained glucose as a carbon source.

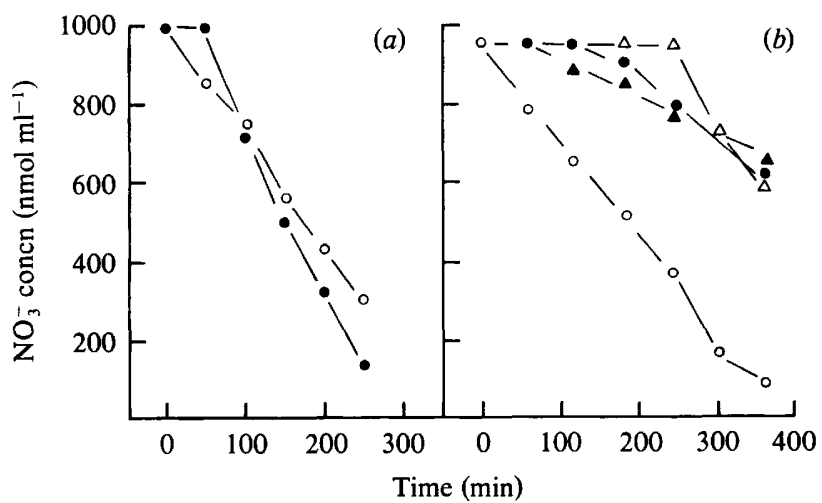

Fig. 2. Effect of glucose and inhibitors on the development of the capacity to take up nitrate during nitrogen starvation. (a) Nitrate uptake was followed in ammonium-grown cultures that were nitrogenstarved for $3 \mathrm{~h}$ with $(\mathrm{O})$ or without $(O) 1 \%(\mathrm{w} / \mathrm{v})$ glucose. Both cultures contained glucose immediately before addition of $1 \mathrm{~mm}$-nitrate. (b) Nitrate uptake was followed in ammonium-grown cultures that were nitrogen-starved for $3 \mathrm{~h}$ in the absence of inhibitors $(O)$ or in the presence of $20 \mu \mathrm{g}$ cycloheximide $\mathrm{ml}^{-1}(\Delta), 5 \mu \mathrm{g}$ antimycin $\mathrm{A} \mathrm{ml} \mathrm{m}^{-1}(\triangle)$ or $1 \mathrm{~mm}-6$-methyl purine $(\bigcirc)$. After treatment, cultures were washed in normal nitrogen-free medium and incubated with nitrate and glucose in the absence of inhibitors.

as electron donor, was approximately four times greater than NADPH-NR activity. In some extracts NADPH-NR activity was very labile.

To study the regulation of NR activity in $S$. roseus cultures, we developed a frozen/thawed cell NR assay using reduced benzyl viologen as an electron donor. NADPH was not effective in these assays possibly because frozen/thawed cells are impermeable to it. Cultures grown with ammonia did not contain NR activity but NR activity appeared and increased in these organisms when they were resuspended in nitrate or nitrogen-free medium (Fig. 5a). Moreover, after $4 \mathrm{~h}$, nitrogen-starved cultures contained a NR activity equivalent to $70 \%$ of that found in nitrate-grown cultures. In contrast, cultures resuspended in ammonium-nitrate medium showed no increase in NR activity. Fig. 5(b) shows a similar experiment. Here, ammonium-grown cultures were nitrogen-starved before the addition of nitrate or ammonium-nitrate and both nitrate uptake and NR activity were measured. After $4 \mathrm{~h}$ of nitrogen starvation, NR activity was $12.5 \mathrm{nmol} \mathrm{m^{-1 }}\left(10^{8} \text { cells }\right)^{-1}$. When nitrate was added to these cultures it was taken up rapidly $\left(5 \mathrm{nmol} \mathrm{min} \mathrm{m}^{-1}\left(10^{8} \text { cells }\right)^{-1}\right.$ and there was a stimulation in the increase of NR activity. 


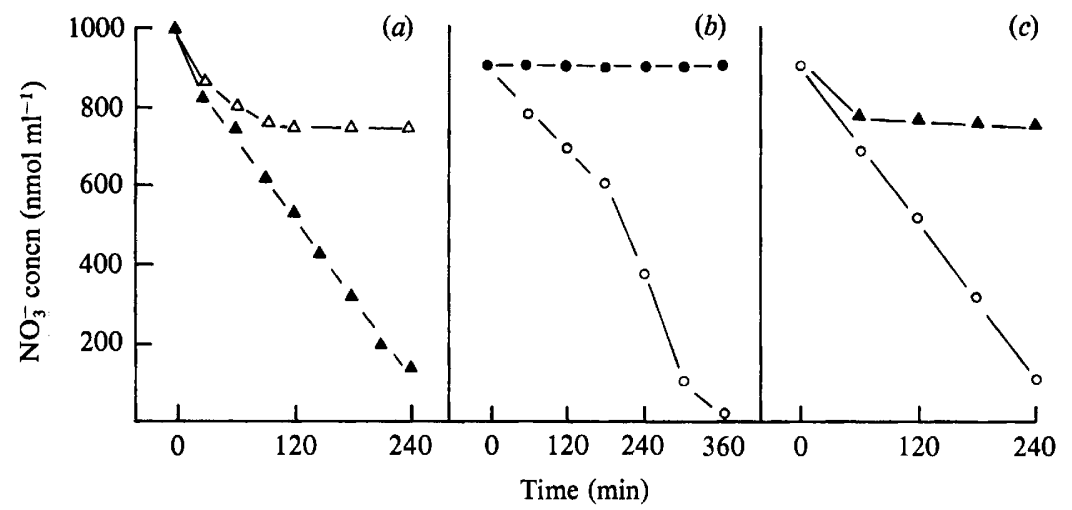

Fig. 3. Effect of glucose and inhibitors on nitrate uptake. Nitrate-grown cultures were resuspended in fresh medium containing $1 \mathrm{~mm}$-nitrate $(a)$ with $(\Delta)$ or without $(\Delta) 1 \%(w / v)$ glucose, $(b)$ with glucose under aerobic $(O)$ or anaerobic $(O)$ conditions, $(c)$ with glucose in the absence $(O)$ or presence $(\boldsymbol{A})$ of antimycin $\mathrm{A}\left(5 \mu \mathrm{g} \mathrm{ml}^{-1}\right)$. Anaerobic cultures were incubated in $250 \mathrm{ml}$ Dreschel bottles and bubbled with oxygen-free nitrogen.

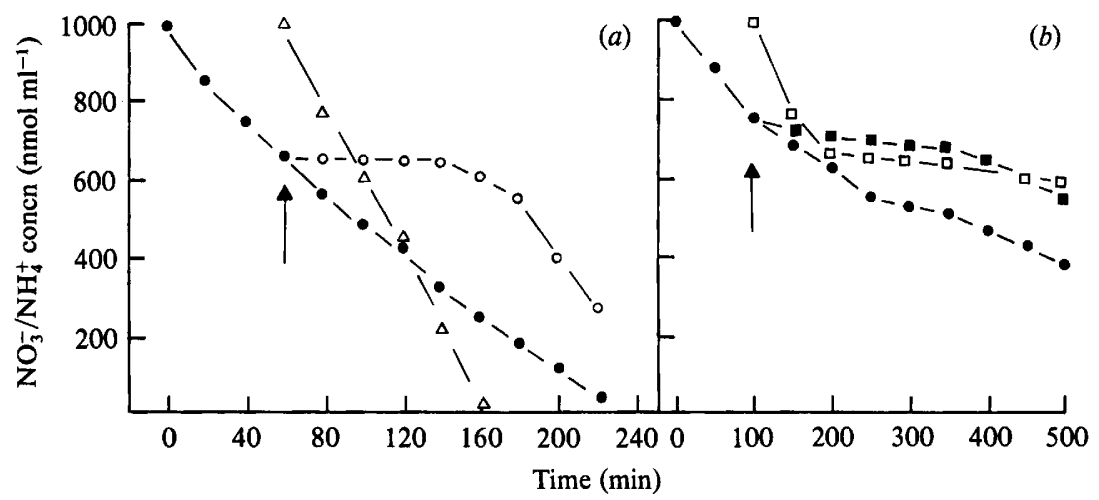

Fig. 4. Effect of ammonium and nitrite on nitrate uptake. Nitrate-grown cultures were transferred to fresh nitrate medium: $(a)$ nitrate uptake in the absence of ammonium (O); nitrate uptake after the addition (arrow) of $1 \mathrm{mm-ammonium}(\mathrm{O})$; ammonium uptake $(\triangle) .(b)$ Nitrate uptake in the absence of nitrite (O); nitrate uptake after addition (arrow) of $0.2 \mathrm{~mm}$-nitrite ( $\square$ ); nitrite uptake ( $\square$ ). All cultures contained glucose as a carbon source.

Table 1. NR activity in cell-free extracts of Sporobolomyces roseus

\begin{tabular}{lc}
\multicolumn{1}{c}{ Addition* } & NR activity \\
NADH & 0 \\
NADH + FAD & 0 \\
NADPH & 1.62 \\
NADPH + FAD & 6.46 \\
NADPH + FMN & 1.62 \\
BVH & 24.85
\end{tabular}

* BVH, reduced benzyl viologen; FAD, flavin adenine dinucleotide; FMN, flavin mononucleotide. $\dagger \mathrm{NR}$ activities are expressed as $\mathrm{nmol} \mathrm{min}^{-1}$ (mg protein) ${ }^{-1}$.

After $3 \mathrm{~h}$ these cultures contained a NR activity of $40 \mathrm{nmol} \mathrm{m^{-1 }}\left(10^{8} \text { cells }\right)^{-1}$. During this period the organisms maintained a constant rate of nitrate uptake. When nitrogen-starved cultures received ammonium and nitrate, there was little nitrate uptake $\left[0.5 \mathrm{nmol} \mathrm{min}{ }^{-1}\right.$ $\left.\left(10^{8} \text { cells }\right)^{-1}\right]$ although NR activity continued to increase at a rate similar to that which occurred in cultures that did not receive nitrogen. 


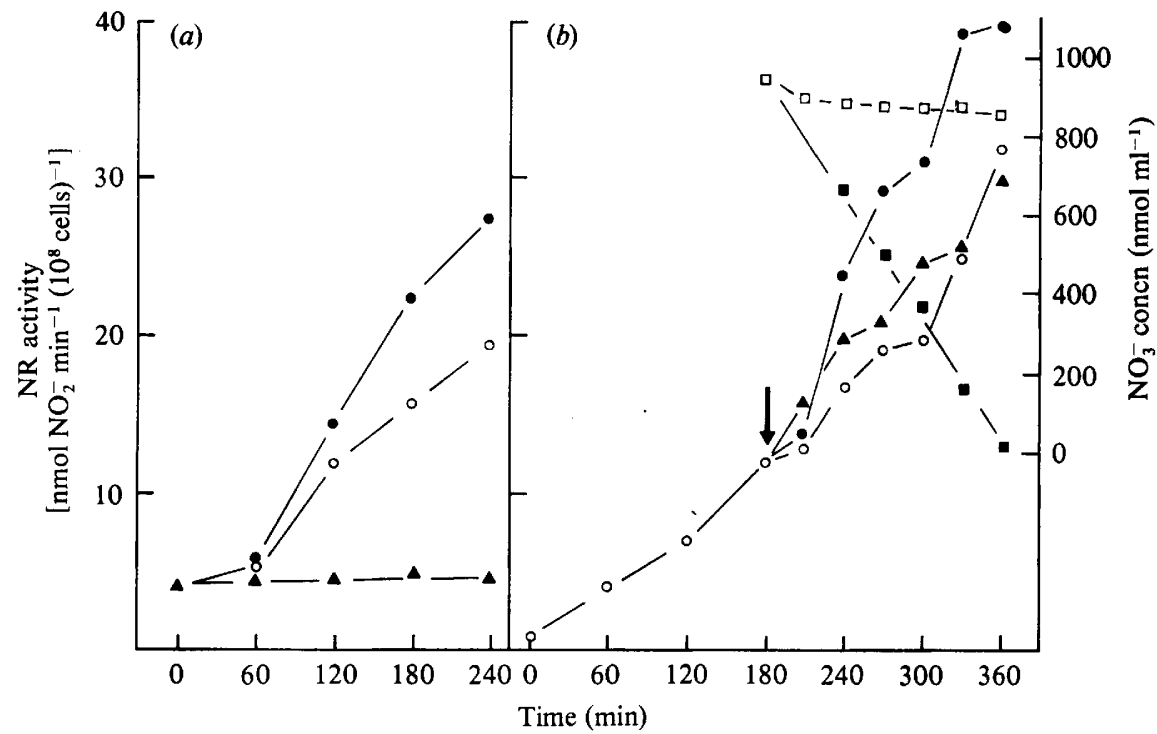

Fig. 5. Appearance of NR activity in ammonium-grown cultures. (a) Ammonium-grown cultures transferred to nitrogen-free medium $(O), 10 \mathrm{~mm}$-nitrate medium $(O)$ or $10 \mathrm{~mm}$-ammonium $+10 \mathrm{~mm}$ nitrate medium $(\boldsymbol{\Delta})$. (b) Ammonium-grown cultures transferred to nitrogen-free medium for $3 \mathrm{~h}$ before addition (arrow) of $1 \mathrm{~mm}$-nitrate $(\boldsymbol{O}), 1 \mathrm{~mm}$-ammonium $+1 \mathrm{~mm}$-nitrate $(\boldsymbol{\Delta})$ or nothing $(\mathrm{O})$. Nitrate uptake by cultures that received nitrate only $(\square)$ and nitrate + ammonium $(\square)$. NR activity was measured in frozen/thawed cells by the terminal NR assay.

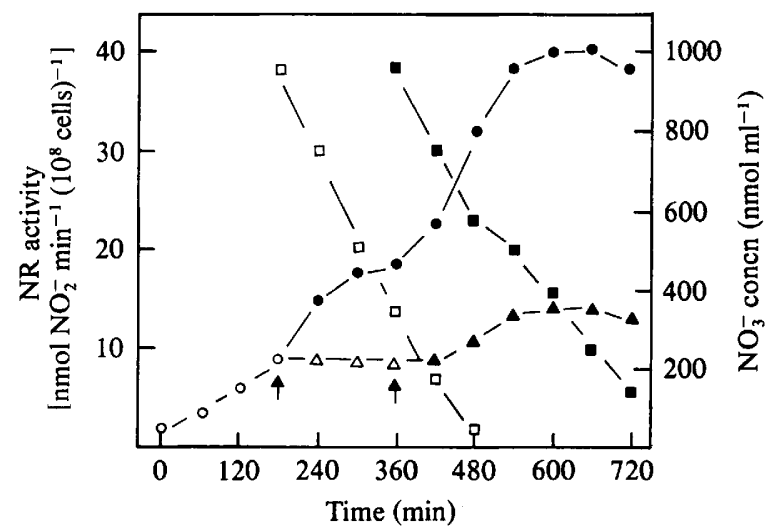

Fig. 6. Effect of cycloheximide on nitrate uptake capacity and the development of NR activity in nitrogen-starved cultures. NR activity was measured in an ammonium-grown culture after transfer to nitrogen-free medium $(O)$. After $3 \mathrm{~h}$ the culture was divided into two and each received additions (first arrow). One culture received $1 \mathrm{mM}$-nitrate and NR activity $(O)$ and nitrate uptake $(\square)$ were followed. The other culture received cycloheximide $\left(20 \mu \mathrm{g} \mathrm{ml}^{-1}\right)$ and $\mathrm{NR}$ activity was followed for a further $3 \mathrm{~h}$ $(\triangle)$. This culture then received $1 \mathrm{~mm}$-nitrate (second arrow) and NR activity $(\boldsymbol{\Delta})$ and nitrate uptake $(\boldsymbol{\square})$ were followed. NR was measured in frozen/thawed cells by the terminal NR assay.

In another experiment (Fig. 6) organisms were nitrogen-starved for $3 \mathrm{~h}$, after which one culture received nitrate and the other received cycloheximide. The culture that received nitrate took it up at a rate of $3.2 \mathrm{nmol} \mathrm{m^{-1 }}\left(10^{8} \text { cells }\right)^{-1}$ and NR activity increased from 9 to $40 \mathrm{nmol} \mathrm{m^{-1 }}\left(10^{8} \text { cells }\right)^{-1}$. NR activity did not increase in cultures that received cycloheximide. After $3 \mathrm{~h}$ with cycloheximide the other culture received nitrate which was taken up immediately at an overall rate of $2 \cdot 3 \mathrm{nmol} \mathrm{min}^{-1}\left(10^{8} \text { cells }\right)^{-1}, 72 \%$ of that by the culture that did 


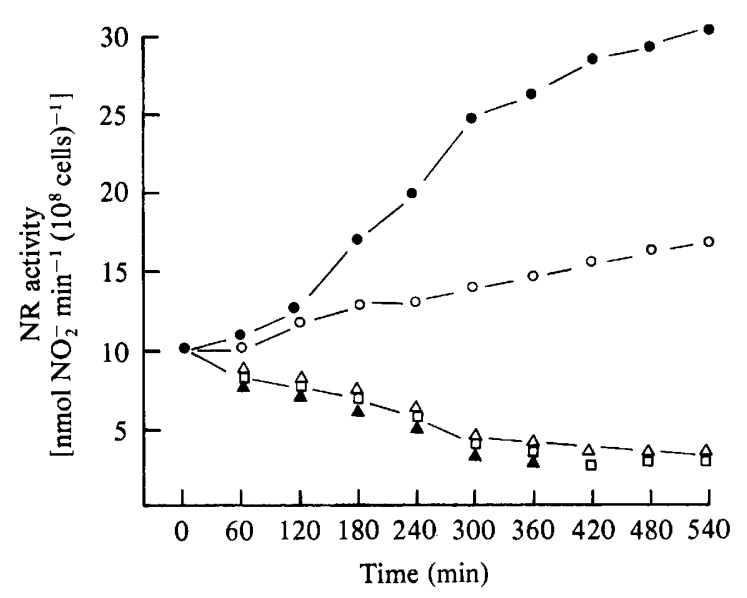

Fig. 7. Effect of nitrogen starvation, carbon starvation and ammonium on NR activity in nitrategrown cultures. Cultures were transferred to fresh medium containing $10 \mathrm{~mm}$-nitrate $(\mathrm{O}), 10 \mathrm{~mm}$ ammonium $(\triangle), 10 \mathrm{~mm}$-nitrate $+10 \mathrm{~mm}$-ammonium $(\boldsymbol{\Delta})$, no nitrogen $(O)$ or $10 \mathrm{~mm}$-nitrate but no glucose $(\square)$. NR activity was measured in frozen/thawed cells by the terminal NR assay.

not receive cycloheximide. In contrast, NR activity in the culture with cycloheximide was stimulated little after nitrate addition; the level of NR activity attained was $35 \%$ of that in cultures that did not receive cycloheximide.

Fig. 7 shows the effect of nitrogen source and glucose on the maintenance of NR activity in nitrate-grown cultures. At zero-time these cultures contained an NR activity of approximately $10 \mathrm{nmol} \mathrm{m^{-1 }}\left(10^{8} \text { cells }\right)^{-1}$. After $9 \mathrm{~h}$ in fresh nitrate medium, NR activity increased by threefold. NR activity also increased in cultures resuspended in nitrogen-free medium but to a much lesser extent. NR activity decreased in cultures resuspended in nitrate medium minus a carbon source. Similarly, NR activity decreased if cultures were resuspended in ammonium medium or medium containing nitrate and ammonium. Decreases in NR activity were similar in these cultures with $50 \%$ loss after 4 or $5 \mathrm{~h}$.

\section{DISCUSSION}

Ammonium-grown cultures of $S$. roseus did not take up nitrate or contain NR activity. However, the organisms acquired the capacity to assimilate nitrate after a lag period of $50 \mathrm{~min}$ in nitrate medium. Nitrate was not essential to 'induce' this capacity since it developed in nitrogen-starved cultures (Fig. 1). This is in contrast to results obtained with filamentous ascomycetes, where the development of the capacity to assimilate nitrate requires induction by nitrate or nitrite (Pateman \& Kinghorn, 1976; Garrett \& Amy, 1978), but is similar to results obtained with microalgae (Morris \& Syrett, 1965; Syrett \& Hipkin, 1973; Cresswell \& Syrett, 1979) and other species of yeasts such as Candida utilis, C. nitratophila and Rhodotorula glutinis (A. H. Ali \& C. R. Hipkin, unpublished results).

In $S$. roseus, development of the capacity to assimilate nitrate during nitrogen starvation required metabolic energy, functional transcription and protein synthesis (Fig. 2) and, once developed, nitrate assimilation was energy-dependent (Fig. 3). One explanation for these results is that a nitrate carrier protein, not present in ammonium cultures, has to be synthesized for nitrate to be assimilated and energy is required for it to function. Unfortunately, we were unable to show an energy-dependent, intracellular accumulation of nitrate against a concentration gradient in $S$. roseus and consequently we have no unequivocal evidence for an active nitrate uptake system like that described for the diatom Phaeodactylum tricornutum (Cresswell \& Syrett, 1979). An alternative explanation is that nitrate uptake is driven by diffusion along a concentration gradient maintained by the intracellular removal of nitrate by nitrate reduction 
(Pateman \& Kinghorn, 1976). If this were so, however, one might expect a close coupling between nitrate uptake and nitrate reduction, particularly when nitrate assimilation is perturbed. Two types of perturbation experiments are described here. Firstly, the addition of ammonium to cultures assimilating nitrate resulted in an immediate and almost complete inhibition of nitrate uptake but not a comparable lowering of NR activity (Figs 4 and $5 b$ ). Ammonium addition did lower the rate of increase in NR activity in such cultures however, and this, presumably, was the result of the inhibition of nitrate uptake. Secondly, the addition of cycloheximide which resulted in a marked inhibition of increases in NR activity resulted in only a small inhibition of nitrate uptake (Fig. 6). Evidently, potential nitrate reduction is not coupled closely with nitrate uptake and, apparently, does not limit nitrate assimilation in $S$. roseus. We suggest that either uptake and reduction are coupled by the supply of reduced pyridine nucleotide which limits actual nitrate reduction in vivo and the assimilation of exogenous ammonium makes reducing power unavailable for nitrate reduction, or nitrate uptake and nitrate reduction are two, separate metabolic processes. Pateman \& Kinghorn (1976) suggested the possibility of a facilitated diffusion of nitrate coupled with nitrate reduction in fungi. Such a model may encompass most of the alternative mechanisms suggested here. In particular, ammonium inhibition could act at the level of uptake or reduction and nitrite inhibition (Fig. $4 b$ ) could be explained by competition for binding sites on a translocator.

NR activity in cell-free extracts of $S$. roseus was NADPH-specific and required flavin adenine dinucleotide for maximum activity (Table 1). Thus, this organism resembles filamentous fungi such as Aspergillus (MacDonald \& Coddington, 1974), Neurospora (Pan \& Nason, 1978) and Penicillium (Renosto et al., 1981) but differs from other yeasts such as Torulopsis (Rivas et al., 1973) and Hansenula (Zauner \& Dellweg, 1983), which contain NR that can utilize electrons from NADH and NADPH. However, NR activity in $S$. roseus differs from that of filamentous fungi and all other yeasts we have studied in being extensively derepressed in nitrogen-starved cultures (Fig. 5). In this respect $S$. roseus resembles some unicellular algae (Syrett \& Hipkin, 1973; Hipkin et al., 1983). Studies on the regulation of NR in S. roseus (Fig. 7) indicate that it is repressed by ammonium or products of ammonium assimilation. Thus although high NR activities are maintained in nitrogen-free culture, in medium containing ammonium or ammonium and nitrate there is an equal loss of activity; the ammonium effect cannot be simply a result of inducer (nitrate) exclusion. Nitrate also plays a role in the regulation of NR in $S$. roseus since it stimulated increases in NR activity in nitrogen-starved cultures (Figs 5,6 and 7).

Ammonium repression of NR was also observed when ammonium plus nitrate was added to ammonium-grown cultures (Fig. 5a). However, when cultures were nitrogen-starved before addition of ammonium plus nitrate, derepression of NR activity was not prevented (Fig. $5 b$ ). At present one can only speculate on reasons for this. One possible explanation is that repressor molecules, perhaps glutamine, do not accumulate when ammonium is assimilated rapidly in derepressed, nitrogen-starved cultures. Alternatively, NR activity might continue to increase under these conditions, despite repression, as a result of the assembly of enzyme subunits formed during nitrogen starvation.

Our results indicate that several features of nitrate assimilation in the basidiomycete yeast Sporobolomyces roseus distinguish it from other yeasts and filamentous fungi but resemble features described for unicellular algae. This organism is notable for exhibiting a marked derepression of the ability to take up and reduce nitrate after nitrogen starvation.

\section{REFERENCES}

Brown, C. M., Macdonald-Brown, D. S. \& Meers, J. L. (1974). Physiological aspects of microbial inorganic nitrogen metabolism. Advances in Microbial Physiology 11, 1-52.

CAwSE, P. A. (1967). The determination of nitrate in soil solutions by ultraviolet spectrophotometry. Analyst 92, 311-315.

Cresswell, R. C. \& Syrett, P. J. (1979). Ammonium inhibition of nitrate uptake by the diatom, Phaeodactylum tricornutum. Plant Science Letters 14, 321-325.
Everest, S. A., Hipkin, C. R. \& Syrett, P. J. (1984). The effect of phosphate and flavin adenine dinucleotide on nitrate reductase activity of some unicellular marine algae. Journal of Experimental Marine Biology and Ecology 76, 263-275.

Ferguson, A. R. \& Sims, A. P. (1971). Inactivation in vivo of glutamine synthetase and NAD-specific glutamate dehydrogenase: its role in the regulation of glutamine synthesis in yeasts. Journal of General Microbiology 69, 423-427. 
GARrett, R. N. \& AMY, N. K. (1978). Nitrate assimilation in fungi. Advances in Microbial Physiology 18, 1-65.

Gregory, P. H. \& Hirst, J. M. (1957). The summer air-spora at Rothamsted in 1952. Journal of General Microbiology 17, 135-152.

Guerrero, M. G., VeGa, J. M. \& Losada, M. (1981). The assimilatory nitrate-reducing system and its regulation. Annual Review of Plant Physiology 32, 169-204.

HARTREe, E. F. (1972). A modification of the Lowry method that gives a linear photometric response. Analytical Biochemistry 48, 422-427.

Hipkin, C. R., Thomas, R. J. \& Syrett, P. J. (1983). Effects of nitrogen deficiency on nitrate reductase, nitrate assimilation and photosynthesis in unicellular marine algae. Marine Biology 77, 101-105.

LAST, F. T. (1955). Seasonal incidence of Sporobolomyces on cereal leaves. Transactions of the British Mycological Society 38, 221-239.

MacDonald, D. W. \& Coddington, A. (1974). Properties of the assimilatory nitrate reductase from Aspergillus nidulans. European Journal of Biochemistry 76, 441-446.

Morris, I. \& SYRETT, P. J. (1965). The effect of nitrogen starvation on the activity of nitrate reductase and other enzymes in Chlorella. Journal of General Microbiology 38, 21-28.

PAN, S. \& NASON, A. (1978). Purification and characterisation of homogeneous assimilatory reduced nicotinamide adenine dinucleotide phosphate-nitrate reductase from Neurospora crassa. Biochimica et biophysica acta 523, 297-313.
Pateman, J. A. \& Kinghorn, J. R. (1976). Nitrogen metabolism. In The Filamentous Fungi, vol. 2, pp. 159-237. Edited by J. E. Smith \& D. R. Berry. London: Edward Arnold.

PAYNe, W. J. (1973). Reduction of nitrogenous oxides by microorganisms. Bacteriological Reviews 37, 409451.

Phaff, H. J. (1970). Sporobolomyces Kluyver et van Niel. In The Yeasts, A Taxonomic Study, pp. 831862. Edited by J. Lodder. Amsterdam \& London: North Holland Publishing Company.

Renosto, F., Ornitz, D. M., Peterson, D. \& Segel, I. H. (1981). Nitrate reductase from Penicillium chrysogenum. Journal of Biological Chemistry 256, 8616-8625.

Rivas, J., Guerrero, M. G., Paneque, A. \& Losada, M. (1973). Characterization of the nitrate-reducing system of the yeast Torulopsis nitratophila. Plant Science Letters 1, 105-113.

Scholl, R. L., HaRper, J. E. \& Hageman, R. H. (1974). Improvements of the nitrite color development in assays of nitrate reductase by phenazine methosulfate and zinc acetate. Plant Physiology 53, 825-828.

SYRETT, P. J. \& HIPKIN, C. R. (1973). The appearance of nitrate reductase activity in nitrogen-starved cells of Ankistrodesmus braunii. Planta 111, 57-64.

ZAUNer, E. \& Dellweg, H. (1983). Purification and properties of the assimilatory nitrate reductase from the yeast Hansenula anomala. European Journal of Applied Microbiology and Biotechnology 17, 90-95. 